\author{
Asian Journal of \\ Medical and Biological Research \\ ISSN 2411-4472 (Print) 2412-5571 (Online) \\ www.ebupress.com/journal/ajmbr
}

\title{
Article \\ Impact of stocking density on growth and production performance of monosex tilapia (Oreochromis niloticus) in ponds
}

\author{
Md. Mamunur Rahman ${ }^{1 *}$, Debashis Kumar Mondal ${ }^{2}$, Md. Rurul Amin $^{1}$ and Mohammad Golam Muktadir ${ }^{1}$ \\ ${ }^{1}$ Department of Aquaculture, Bangladesh Agricultural University, Mymensingh-2202, Bangladesh \\ ${ }^{2}$ Bangladesh Fisheries Research Institute, Brackish Water Station, Paikgacha, Khulna, Bangladesh
}

*Corresponding author: Md. Mamunur Rahman, Department of Aquaculture, Bangladesh Agricultural University, Mymensingh-2202, Bangladesh. E-mail: mamunurrahman125@gmail.com

Received: 07 September 2016/Accepted: 22 September 2016/ Published: 29 September 2016

\begin{abstract}
Stocking density is considered one of the important factors affecting fish growth. The study was aimed to compare the growth parameters of monosex tilapia at various stocking densities. The experiment was carried out during the period from 06 August to 22 December 2014. Three stocking densities were used as 125, 250 and 375 fish/dec and designated as treatment $T_{1}, T_{2}$ and $T_{3}$ respectively each having two replicates. All the fishes were of same age group having average initial body weight of $1.34 \mathrm{~g}$. A commercial feed was supplied at the rate of $40 \%$ of the body weight and then gradually it was readjusted to $20 \%, 10 \%, 5 \%$ and $3 \%$ respectively and continued up to the end of the experiment. The water quality parameters were monitored at 14 days interval and the ranges were: temperature 19.34 to $31.40^{\circ} \mathrm{C}$, pH 6.83 to 8.03 , dissolved oxygen 4.78 to $6.82 \mathrm{mg} / \mathrm{l}$ and transparency 29.02 to $49.45 \mathrm{~cm}$. The result of the present study showed that the mean weight gain was significantly $(\mathrm{P}<0.01)$ highest in $\mathrm{T}_{1}(120.58 \mathrm{~g})$ followed by $\mathrm{T}_{2}(89.74 \mathrm{~g})$ and $\mathrm{T}_{3}(74.58 \mathrm{~g})$. The average specific growth rates (SGR) was 2.590, 2.560 and 2.598 (\%/day) in treatment $\mathrm{T}_{1}, \mathrm{~T}_{2}$ and $\mathrm{T}_{3}$ respectively. There was significant $(\mathrm{P}<0.01)$ differences among the survival rate. The survival rate $87 \%$ was significantly highest in $\mathrm{T}_{1}$ followed by $76 \%$ in $\mathrm{T}_{2}$ and $69 \%$ in $\mathrm{T}_{3}$. The fish productions were $13.25,17.30$ and $19.64 \mathrm{~kg} / \mathrm{decimal}$ in $\mathrm{T}_{1}, \mathrm{~T}_{2}$ and $\mathrm{T}_{3}$ respectively. Although the highest production was obtained in $\mathrm{T}_{3}$ but individually growth performance of monosex tilapia was highest in $\mathrm{T}_{1}$. The highest net profit was found (BDT 3,373.30) in $\mathrm{T}_{1}$ compared to $_{2}$ (BDT 3,017) and $\mathrm{T}_{3}$ (BDT 2,918). The highest benefit cost ratio (BCR) was 1.79 in $\mathrm{T}_{1}$ followed by 1.44 in $\mathrm{T}_{2}$ and 1.28 in $T_{3}$. Based on the result of present experiment, fish farmers might be suggested to rear tilapia at lower stocking density to get higher growth, survival and benefit in a short period of time.
\end{abstract}

Keywords: stocking density; monosex tilapia; growth; production performance

\section{Introduction}

Aquaculture is the fastest-growing food-producing sector and plays an important role in enhancing global food security, alleviating poverty and human dependence on depleted natural fish stocks (Al Hassan et al., 2012). Tens of millions of people are engaged in aquaculture production with majority involved in small-scale production (Subasinghe et al., 2012). Tilapia is seen as one of the most significant fish species which can reduce the gap of increasing worldwide demand for protein sources (Romano and $\mathrm{Ng}, 2013$ ). Its production worldwide has been increased from 1,099,268 tons in 1999 to about 3,500,000 tons in 2010 (FAO, 2012). Tilapia is recognized as one rang of aquaculture system from single small scale waste fed fish ponds to intensive culture (Pullin, 1985). Overall performance of Nile tilapia and other fast growing tilapias have proved that they are no longer pests but have become to be known as `aquatic chicken' (Maclean, 1984). Tilapia (Oreochromisniloticus) is a hardy fish that can survive in shallow and turbid water conditions and a good converter of organic matter into high quality protein (Stickney et al., 1979). There are four strategies for mono-sex culture i.e. manual process by visual examination, hybridization (crossbreeding of two appropriate species); gene manipulation and 
masculinization via steroid hormone. The stocking density is the major concern for mono-culture. Sometimes excellent fish fry do not perform satisfactory growth unless correct stocking practices (Sanches and Hayashi, 1999). The optimum stocking density ensures sustainable aquaculture providing proper utilization of feed, maximum production, sound environment and health. In comparison to low stocking density, high stocking density exerts many negative impacts such as competition for food and shelter and rapid outbreak of disease if occurred. The objectives of the study to evaluate the effect of stocking density on growth of monosex tilapia in earthen ponds and to compare the production of monosex tilapia at various stocking densities.

\section{Materials and Methods}

The experiment was carried out in the Field Laboratory Complex of Bangladesh Agricultural University for a period of 134 days. The experiment was 3 treatments and 2 replications with different stocking densities (Table1). The pond size was 2 decimal each. Data was collected fortnightly to assess the impact of stocking density on growth and production of monosex tilapia.

Table 1. Research layout of mono-sex tilapia rearing.

\begin{tabular}{lllll}
\hline Treatment & Replication & Pond size (Decimal) & Stocking density/decimal & Stocking size (g) \\
\hline \multirow{2}{*}{$\mathrm{T}_{1}$} & $\mathrm{R}_{1}$ & 2 & 125 & \\
& $\mathrm{R}_{2}$ & 2 & 125 & 1.34 \\
$\mathrm{~T}_{2}$ & $\mathrm{R}_{1}$ & 2 & 250 & \\
& $\mathrm{R}_{2}$ & 2 & 250 & \\
$\mathrm{~T}_{3}$ & $\mathrm{R}_{1}$ & 2 & 375 & \\
& $\mathrm{R}_{2}$ & 2 & 375 & \\
\hline
\end{tabular}

Mono-sex male tilapia (Oreochromis niloticus) spawn were collected from the "Kader Hatchery" in Tarakanda upazilla, Mymensingh. During stocking sufficient care was taken about the physico-chemical condition of the pond water. Throughout the experiment commercial floating feeds named "Mega Fish Feed" was selected. This floating feed was used due to having high nutritive value. During the culture period feed was supplied three times per day at the rate of $40 \%$ of the body weight and it was readjusted to $20 \%, 10 \%, 5 \%$ and $3 \%$ respectively after 15 days interval and continued up to the end of the experiment. Sampling was performed by using a seine net. During each sampling 10 fish were collected from each pond. Sampling was done at an interval of 15 days. Water samples were collected between 08.00-09.00 a.m. at biweekly interval. The physico-chemical parameters like temperature $\left({ }^{\circ} \mathrm{C}\right)$, dissolved oxygen $\left(\mathrm{mg} \mathrm{L}^{-1}\right), \mathrm{pH}$, and transparency $(\mathrm{cm})$ were recorded by respective test kits. Growth performance was evaluated as mean cumulative weight $(\mathrm{g})$, mean weight gain $(\mathrm{g})$, percent weight gain $(\%)$, average daily gain (g),specific growth rate (SGR)(\%/ day), survival rate (\%) and production ( $\mathrm{kg} / \mathrm{dec} / 134$ days) by using the formulae below:

a) Mean cumulative weight $(\mathrm{g})=\frac{\text { Total live weight }}{\text { Total numbers }}$

b) Mean weight gain $(\mathrm{g})=$ Mean final fish weight $(\mathrm{g})$ - Mean initial fish weight $(\mathrm{g})$

c) Percent weight gain $(\%)=\frac{\text { Mean final weight }(\mathrm{g})-\text { Mean initial weight }(\mathrm{g})}{\text { Mean initial weight }(\mathrm{g})} \times 100$

d) Average daily gain $(\mathrm{g})=\frac{\text { Mean final weight }(\mathrm{g})-\text { Mean initial weight }(\mathrm{g})}{\mathrm{T}_{2}-\mathrm{T}_{1}}$

Where, $\mathrm{T}_{2}-\mathrm{T}_{1}=$ Duration of experiment.

e) Specific growth rate $(\mathrm{SGR})(\% /$ day $)=\frac{\log \mathrm{W}_{2}-\log \mathrm{W}_{1}}{\mathrm{~T}_{2}-\mathrm{T}_{1}} \times 100$

Where, $\mathrm{W}_{1}=$ Initial live body weight $(\mathrm{g})$ of tilapia at time $\mathrm{T}_{1}$ (day)

$\mathrm{W}_{2}=$ Final live body weight $(\mathrm{g})$ of tilapia at time $\mathrm{T}_{2}$ (day)

$\mathrm{T}_{2}-\mathrm{T}_{1}=$ Duration of the experiment (day)

f) Survival rate $(\%)=\frac{\text { No. of fish harvest }}{\text { No. of fish stocked }} \times 100$

g) Production (kg/dec/134days)

Production $(\mathrm{kg} / \mathrm{dec} / 134$ days $)=\frac{\text { No. of fish harvested } \times \text { Average final weight of fish }(\mathrm{g})}{1000}$

One way analysis of variance (ANOVA) was used to determine the effects of stocking density on the growth and production of monosex Tilapia. This was followed by Duncan's New Multiple Range Test (DNMRT) at 1\% level of significance to study any difference among treatment means (Zar, 1984). 
Benefit-cost ratio $(\mathrm{BCR})=\frac{\text { Total income }}{\text { Total cost }}$

$\mathrm{R}=\mathrm{I}-(\mathrm{Fc}+\mathrm{Vc})$

Where,

$\mathrm{R}=$ net return;

I = Totalincome from tilapia sale;

$\mathrm{Fc}=$ Fixed costs and

$\mathrm{Vc}=$ Variable costs.

\section{Results and Discussion}

The temperature ranged from 19.34 to $31.40^{\circ} \mathrm{C}$ during the study period. The maximum water temperature was $31.40^{\circ} \mathrm{C}$ in $\mathrm{T}_{1}$ on 17 September 2014 and the minimum water temperature was found $19.34^{\circ} \mathrm{C}$ in $\mathrm{T}_{2}$ on 10 December 2014. The mean ( $\pm \mathrm{SE})$ values of water temperature were $26.89 \pm 1.17,26.79 \pm 1.25$ and $26.78 \pm$ $1.14^{\circ} \mathrm{C}$ in $\mathrm{T}_{1}, \mathrm{~T}_{2}$ and $\mathrm{T}_{3}$. which was within the range for suitable culture of fish reported by Kohinoor (2000), Islam (2007), Hossain (2007) and Begum (2009) who measured water temperature in ponds of BAU, Campus Mymensingh and found to vary from 18.50 to $32.90^{\circ} \mathrm{C}, 22$ to $32.20^{\circ} \mathrm{C}, 26.0$ to $32.80^{\circ} \mathrm{C}$ and 26.30 to $33.00^{\circ} \mathrm{C}$ respectively. Haque (2014) found temperature 20.32 to $33.47^{\circ} \mathrm{C}$ which is more or less similar to our present study. The dissolved oxygen fluctuation was more or less similar in all of the three treatments. The dissolved oxygen ranged from 4.78 to $6.82 \mathrm{mg} / \mathrm{l}$. The maximum dissolved oxygen was $6.82 \mathrm{mg} / \mathrm{l}$ in treatment $\mathrm{T}_{1}$ on 03 September 2014 and the minimum dissolved oxygen was found $4.78 \mathrm{mg} / \mathrm{l}$ in treatment $\mathrm{T}_{3}$ on 10 December 2014. The mean $( \pm$ SE) values of dissolved oxygen content were $5.889 \pm 0.194,5.826 \pm 0.168$ and $5.443 \pm 0.139 \mathrm{mg} / \mathrm{l}$ in $\mathrm{T}_{1}, \mathrm{~T}_{2}$ and $\mathrm{T}_{3}$ respectively. According to Rahman (1992) dissolved oxygen content of a productive pond should be $5.0 \mathrm{ppm}$ or more. DoF (1996) reported that the range of suitable dissolved oxygen for fish culture would be 5.50 to $6.50 \mathrm{mg} / \mathrm{l}$. The concentration of dissolved oxygen in the present study was similar to findings of Dewan (1991) 2.2 to $8.8 \mathrm{mg} / \mathrm{l}$; Alam et al. (1997) 4.0 to $7.0 \mathrm{mg} / \mathrm{l}$; Daud pota et al. (2014) 5.8 to $6.4 \mathrm{mg} / \mathrm{l}$; Haque (2014) 4.98-5.71 mg/l; and Sayeem (2014) 4.0 to $6.0 \mathrm{mg} / \mathrm{l}$. The $\mathrm{pH}$ ranged from 6.83 to 8.03. The highest value of $\mathrm{pH}$ was 8.03 in $\mathrm{T}_{2}$ on 29 October 2014 and the lowest value was 6.83 in $\mathrm{T}_{3}$ at the same date. The mean $( \pm \mathrm{SE})$ values of $\mathrm{pH}$ were $7.399 \pm 0.066,7.608 \pm 0.066$ and $7.472 \pm 0.119$ in $\mathrm{T}_{1}, \mathrm{~T}_{2}$ and $\mathrm{T}_{3}$, respectively. Islam (2007) reported that the range of $\mathrm{pH}$ of water body suitable for fish culture would be 6.8 to 8.27 . Begum (2009) and Kohinoor (2000) reported pH 7.7-8.25 and 6.5-8.0 respectively. According to Alam (2009) the range of $\mathrm{pH}$ would be 7.72-8.3.Transparency varied from 49.45 to $29.02 \mathrm{~cm}$ during the study period. Remarkable variation of water transparency were found in the ponds throughout the study period with the minimum values of 29.02 $\mathrm{cm}$ in $\mathrm{T}_{1}$ on 10 December 2014 and the maximum values of $49.45 \mathrm{~cm}$ in $\mathrm{T}_{3}$ on 06 August 2014. The mean values of water transparency were recorded as $35.83 \pm 1.80,37.68 \pm 1.79$ and $37.52 \pm 1.74 \mathrm{~cm}$ in $\mathrm{T}_{1}, \mathrm{~T}_{2}$ and $\mathrm{T}_{3}$ respectively. Dewan (1991), Nirod(1997), Rahman (2000), Kohinoor (2000), Sarker (2000) who measured water transparency $(\mathrm{cm})$ in ponds of BAU Campus, Mymensingh and found to vary from 54 to 90 $\mathrm{cm}, 25$ to $67 \mathrm{~cm}, 26.5$ to $36.6 \mathrm{~cm}, 15$ to $58 \mathrm{~cm}, 27$ to $35 \mathrm{~cm}$ and 12 to $19 \mathrm{~cm}$, respectively which is more or less similar to our present study.

Table 2. Statistical analysis (ANOVA) for fish growth performances (Average \pm SE) values of tilapia under different treatments during the study period.

\begin{tabular}{|c|c|c|c|c|c|}
\hline Parameters & $\mathbf{T}_{1}$ & $\mathbf{T}_{2}$ & $\mathbf{T}_{3}$ & LSD & Level of sig. \\
\hline Mean initial weight $(\mathrm{g})$ & 1.34 & 1.34 & 1.34 & 0.00 & ND \\
\hline Mean final weight $(\mathrm{g})$ & $44.44 \pm 0.02^{\mathrm{a}}$ & $35.94 \pm 0.34^{\mathrm{b}}$ & $34.25 \pm 0.82^{b}$ & 1.094 & $* *$ \\
\hline Mean weight gain $(\mathrm{g})$ & $49.26 \pm 0.03^{\mathrm{a}}$ & $39.54 \pm 0.39^{b}$ & $37.62 \pm 0.94^{\mathrm{b}}$ & 1.250 & $* *$ \\
\hline Percent weight gain $(\%)$ & $3676.22 \pm 2.45^{\mathrm{a}}$ & $2951.11 \pm 29.58^{b}$ & $2807.56 \pm 70.14^{\mathrm{b}}$ & 93.304 & $* *$ \\
\hline SGR (\%/day) & $2.590 \pm 0.012$ & $2.560 \pm 0.019$ & $2.598 \pm 0.014$ & 0.108 & NS \\
\hline Average daily gain (g) & $0.621 \pm 0.003^{\mathrm{a}}$ & $0.539 \pm 0.003^{b}$ & $0.530 \pm 0.010^{\mathrm{b}}$ & 0.015 & $* *$ \\
\hline Survival rate $(\%)$ & $87.00 \pm 2.00^{\mathrm{a}}$ & $76.00 \pm 1.00^{\mathrm{b}}$ & $69.00 \pm 1.00^{\mathrm{b}}$ & 3.00 & $* *$ \\
\hline $\begin{array}{l}\text { Total production }(\mathrm{kg} / 134 \\
\text { days) }\end{array}$ & $53.03 \pm 2.030^{\mathrm{c}}$ & $69.22 \pm 0.800^{\mathrm{b}}$ & $78.58 \pm 1.100^{\mathrm{a}}$ & 2.993 & $* *$ \\
\hline
\end{tabular}

$* *=$ significant at $1 \%$ level of probability $(\mathrm{P} \leq 0.01)$

$\mathrm{NS}=$ Not significant

Values having a different superscripts are significantly different $(* * \mathrm{P}<0.01)$ (as per DNMRT). 
Table 3. Growth, survival rate and production of monosex tilapia (O. niloticus) under three treatments during the study period form10 August 2014 to 22 December 2014.

\begin{tabular}{|c|c|c|c|c|c|c|c|c|c|}
\hline $\begin{array}{l}\text { Treatme } \\
\text { nts }\end{array}$ & $\begin{array}{l}\text { Stocking of } \\
\text { fish (Initial } \\
\text { no.) }\end{array}$ & $\begin{array}{l}\text { Initial } \\
\text { weight } \\
\text { (g) }\end{array}$ & $\begin{array}{l}\text { Final } \\
\text { weight } \\
\text { (g) }\end{array}$ & $\begin{array}{l}\text { Total } \\
\text { harvest } \\
\text { (Final } \\
\text { no.) } \\
\end{array}$ & $\begin{array}{l}\text { Total } \\
\text { mortali } \\
\text { ty (no.) }\end{array}$ & $\begin{array}{l}\text { Survival } \\
\text { rate }(\%)\end{array}$ & $\begin{array}{l}\text { Total } \\
\text { production } \\
\text { (kg/134 } \\
\text { days) }\end{array}$ & $\begin{array}{l}\text { Production } \\
\text { (kg/dec/134 } \\
\text { days) }\end{array}$ & $\begin{array}{l}\text { Production } \\
\text { (kg/acre/134 } \\
\text { days) }\end{array}$ \\
\hline$\overline{\mathrm{T}_{1}}$ & 500 & & 121.92 & 435 & 65 & 87 & 53.03 & 13.25 & 1325 \\
\hline $\mathrm{T}_{2}$ & 1000 & 1.34 & 91.08 & 760 & 240 & 76 & 69.22 & 17.30 & 1730 \\
\hline $\mathrm{T}_{3}$ & 1500 & & 75.92 & 1035 & 465 & 69 & 78.58 & 19.64 & 1964 \\
\hline
\end{tabular}

Table 4. Benefit-cost analysis of monosex tilapia (O. niloticus) under three different treatments during the study period.

\begin{tabular}{lccc}
\hline Items & $\mathbf{T}_{\mathbf{1}}$ & $\mathbf{T}_{\mathbf{2}}$ & $\mathbf{T}_{\mathbf{3}}$ \\
\hline & Variable cost (BDT) & 100 \\
Pond preparation & 100 & 100 & 1500 \\
Cost of fry & 500 & 1000 & 3990 \\
Artificial Feed cost & 1810 & 3155 & 150 \\
Labor & 150 & 150 & 400 \\
Lease Cost (BDT/dec) & Fixed cost (BDT) & 6140 \\
Total cost & 400 & 400 & 78.58 \\
Total fish production(kg) & 2960 & 4805 & 100 \\
Price of fish/kg & Financial returns (BDT) & 7858 \\
Gross Profit & 53.03 & 69.22 & 2918 \\
Net Profit & 100 & 100 & 1.28 \\
Benefit-cost ratio (BCR) & 5303 & 6922 & 3017 \\
\hline
\end{tabular}

\subsection{Growth and production performances of the fish}

There was significant difference $(\mathrm{p} \leq .01)$ among the different treatments. The highest mean weight gain $(120.58 \pm 1.32 \mathrm{~g})$ was found in treatment $\mathrm{T}_{1}$, whereas the lowest mean weight gain $(74.58 \pm 2.65 \mathrm{~g})$ was found in treatment $\mathrm{T}_{3}$. The present experiment showed the highest mean weight gain of fish in treatment $\mathrm{T}_{1}$ which was stocked at lower densities although same feed and feeding rate were applied in all the treatments. These phenomenon indicated that lower stocking density reduces competition among the fishes which influenced them to take feed properly and it might be absent in the treatments with higher stocking densities. Ahmed et al. (2013) obtained a weight gain of $123.48 \mathrm{~g}$ and $111.82 \mathrm{~g}$ from two different treatments of monosex tilapia for a period of 70 days which were more or less similar to the present study. Ahmed et al. (2015) found the mean lowest weight gain $(94.45 \mathrm{~g})$ which is higher to our present findings. There was significant difference in of percent weight gain $(\mathrm{p}<0.01)$ among the different treatments. The highest mean $( \pm \mathrm{SE})$ value $(8998.507 \pm 98.507)$ was found in $\mathrm{T}_{1}$ where as the lowest mean $( \pm \mathrm{SE})$ value $(5565.671 \pm 197.761)$ of percent weight gain was found in $\mathrm{T}_{3}$. Ahmed et al. (2015) found highest percent weight gain $7310.71 \pm 340.30$ for monosex tilapia treatment $T_{1}$ which is much higher than the value obtained in the present study and $6746.43 \pm 454.93$ for monosex tilapia treatment $\mathrm{T}_{2}$ which is much lower than the value obtained in the present study (Table 3). The results indicated that the growth rates varied in different stocking density which coincides with the findings of Begum (2009), Rubel (2008), Rashid (2008), and Islam (2007). The average values of specific growth rate of monosex tilapia were observed as $2.590 \%$, $2.560 \%$ and $2.598 \%$ in treatments $\mathrm{T}_{1}, \mathrm{~T}_{2}$ and $\mathrm{T}_{3}$, respectively. There was no significant difference $(\mathrm{P}<0.01)$ among the different treatments. Islam (2007), Begum (2009), Rahim (2010) and Ahmed et al. (2015) who recorded specific growth rate ranged 2.363 to $2.655 \%, 3.65$ to $3.79 \%, 3.09$ to $3.34 \%$ and 2.04 to 2.08 . Islam (2007) obtained the highest values of SGR at the lowest stocking densities which coincide with the present findings. The highest survivability was recorded in $\mathrm{T}_{1}(87 \%)$ and the lowest survivability was in $\mathrm{T}_{3}(69 \%)$. There was significant difference $(\mathrm{P}<0.01)$ among the different treatments. Variation in stocking density of fish may change growth and survival rates (Table 3). According to Kohinoor et al. (2007) survival rate of monosex tilapia were varied from $79 \%$ to $92 \%$. The highest production was observed to be $19.64 \mathrm{Kg} / \mathrm{dec} / 134$ days in treatment $\mathrm{T}_{3}$ and the lowest production was observed to be $13.25 \mathrm{Kg} / \mathrm{dec} / 134$ days in treatment $\mathrm{T}_{1}$. Although the mean weight gain in treatment $T_{1}$ was highest but total production was highest in treatment $T_{3}$ which might be due to higher stocking 
densities (Table 2). Begum (2009) observed the highest production was $14.63 \mathrm{~kg} / \mathrm{dec} / 120$ days which is much higher to our present findings. The present result also supports the findings of Haque (2014) and Hasan (2007) who achieved the higher production from higher stocking densities compared to that achieved with the lower ones.

\subsection{Benefit-cost analysis}

From the experiment it was found that the highest net profit was BDT 3,373.30 in $\mathrm{T}_{1}$ followed by BDT 3,017 in $\mathrm{T}_{2}$ and BDT 2,918 in $\mathrm{T}_{3}$. That time the market price was BDT $100 / \mathrm{kg}$ fish. Culture of monosex tilapia $(O$. niloticus) at stocking density (125 fish/dec) showed higher benefit in short period of time. The benefit cost ratio was $1.79,1.44$ and 1.28 in $\mathrm{T}_{1}, \mathrm{~T}_{2}$ and $\mathrm{T}_{3}$, respectively (Table 4). Alim (2013) stated that the benefit-cost ratio was $1.35,1.52$ and 1.30 in $\mathrm{T}_{1}, \mathrm{~T}_{2}$ and $\mathrm{T}_{3}$, respectively which is lower than our present findings. So it can be concluded that the benefit-cost ratio (BCR) in $\mathrm{T}_{1}$ was more beneficial than $\mathrm{T}_{2}$ and $\mathrm{T}_{3}$.

\section{Conclusions}

Under the experimental condition, different treatments showed different growth rates. From the present experiment, it was found that the total production was increased with the increase of stocking density. But the individual fish growth rate was decreased with the increase of stocking density. Present findings indicated that comparatively highest individual weight gain was found in $T_{1}$ which received lower stocking density $(125 \mathrm{fish} / \mathrm{dec})$ and highest production was found in $\mathrm{T}_{3}$ which received higher stocking density ( $375 \mathrm{fish} / \mathrm{dec}$ ). Water quality parameters were found within suitable range. From the experiment it might be suggested that the stocking density (125 fish/decimal) performed the better results and further study is needed to explore the economics of tilapia farming with different stocking densities.

\section{Conflict of interest}

None to declare.

\section{References}

Ahmed GU, N Sultana, M Shamsuddin and MB Hossain, 2013. Growth and production performance of Monosex Tilapia (Oreochromis niloticus) feed with homemade feed in earthen mini ponds. Pakistan J. Biol. Sci., 16: 1781-1785.

Ahmed GU, H Aktar, S Chakma, NA Hasan and M Shamsuddin, 2015. Comparative study on growth of supermale tilapia and monosex tilapia in earthen mini pond. Res. Agric, Lives. and Fish., 2: 169-175.

Alam MJ, ME Haque, DA Jahan and MA Mazid, 1997. Nursery rearing of Macrobrachium rosenbergii using hapa-nets: effects of stocking density. Bangladesh J. Fish. Res., 1: 09-16.

Alim A, 2013. Effects of stocking density on growth and production of monosex male tilapia (Oreochromis niloticus) in ponds, MS Thesis, Department of Aquaculture, Bangladesh Agricultural University, Mymensingh. 55 pp.

Alhassan EH, ED Abarike and CL Ayisi, 2012. Effects of stocking density on the growth and survival of Oreochromis niloticus cultured in hapas in a concrete tank. African J. Agricl. Res., 7: 2405-2411.

Begum M, 2009. Effect of stocking density on the growth and production performance of Mono-sex Tilapia (Oreochromis niloticus) in ponds, MS Thesis, Department of Aquaculture, Bangladesh Agricultural University, Mymensingh. 58 pp.

Cruz EM and M Ridha, 1994. Over-wintering tilapia, Oreochromis spilurus (Gunther), fingerlings using warm underground sea water. Aqua. Fish. Mant., 25: 865-871.

Daudpota AA, IB Kalhoro, SA Shah, H Kalhoro and G Abbas, 2014. Effect of stocking densities on growth, production and survival rate of red tilapia. J. Fish., 2: 180-186.

Dewan S, MA Wahab, MCM Rahman and BK Sarker, 1991. Food selection, selectivity and dietary overlap among planktivorous Chinese and Indian major carp fry and fingerlings grown in extensively managed, rain fed ponds in Bangladesh. Aqua. Fish. Manat., 22: 277-294.

DoF, (Department of Fisheries) 1996. Matsha Pakkah Shankalan. Directorate of Fisheries, Government of Peoples Republic of Bangladesh, Dhaka, Bangladesh. 122 pp.

FAO, 2012. Food and Agriculture Organization of the United Nations, Fisheries and Aquaculture Department, Global Aquaculture Production Statistics for the year 2011. 69 pp.

Haque ABMM, 2014. Optimization of stocking density on growth and production performance of mono-sex tilapia in pond, MS Thesis, Department of Aquaculture, Bangladesh Agricultural University, Mymensingh. $53 \mathrm{pp}$. 
Hossain MS, 2007. Evaluation of rice bran and wheat bran as supplemental feed compared to a commercial feed for the monoculture of GIFT strain (Oreochromis niloticus), MS Thesis, Department of Aquaculture, Bangladesh Agricultural University, Mymensingh. 56 pp.

Islam MS, 2007. Effect of stocking density on the growth and production of GIFT Tilapia (Oreochromis niloticus) in ponds, MS Thesis, Department of Aquaculture, Bangladesh Agricultural University, Mymensingh. 48 pp.

Kohinoor AHM, MG Hussain, MS Islam, SC Mahanta, MZ Ali, MB Tanu, MA Hossain and MA Mazid, 2000. Genetic evaluation of GIFT and existing strains of Nile Tilapia, O. niloticus L, under on-station \& on-farm conditions in Bangladesh. Asian Fish. Sci., 13: 117-126.

Maclean JL, 1984. Tilapia - the aquatic chicken. International Centre for Living Aquatic Resources Management (ICLARM) News Letter, 7: 1-7.

Pullin RSV, 1985. Tilapias: "Every man's fish". Biologist, 32: 84-88.

Rahim A, 2010. Effects of stocking density on growth and production performance of mono-sex Tilapia (Oreochromis niloticus) in ponds, MS Thesis, Department of Aquaculture, Bangladesh Agricultural University, Mymensingh. 47 pp.

Rahman MS, MY Chowdhury, AKMA Haque and MS Haq, 2000. Limnological studies of four ponds. Bangladesh J. Fish., 5: 25-35.

Rashid MH, 2008. Effects of stocking density on the growth and survival and production of GIFT Tilapia (Oreochromis niloticus, L.) reared in recirculatory system in cisterns, MS Thesis, Department of Aquaculture, Bangladesh Agricultural University, Mymensingh. 57 pp.

Romano N, WK Ng, 2013. A review of the nutrition and feeding management of farmed tilapia throughout the culture cycle. Reviews in Aquaculture, 4: 1-35.

Rubel AKMSA, 2008. Effects of stocking density of mono-sex Nile Tilapia (Oreochromis niloticus) on plankton community in pond, MS Thesis, Department of Aquaculture, Bangladesh Agricultural University, Mymensingh. 62 pp.

Sanches LEF and C Hayashi, 1999. Stocking density effect on Nile Tilapia (Oreochromis niloticus) fry performance during sex reversal. Acta Seien., 21: 619-625.

Sayeem AJM, 2014. Monosex gift tilapia (Oreochromis niloticus) fry nursing at farmers ponds in kounia and lalmonirhat sadar upazilas, MS Thesis, Department of Aquaculture, Bangladesh Agricultural University, Mymensingh. $51 \mathrm{pp}$.

Stickney RRJH, RB Geachin and WA Isbell, 1979. Growth of tilapia (Oreochromis niloticus) in ponds with different organic fertilizations. Aqua, 19: 189-194.

Subasinghe R, I Ahmad, L Kassam, S Krishnan, B Nyandat, A Padiyar, M Phillips, M Reantaso, W Miao and K Yamamoto, 2012. Protecting small-scale farmers: a reality within a globalized economy? In: RP Subasinghe, JR Arthur, DM Bartley, SSD Silva, M Halwart, N Hishamunda, CV Mohan and P Sorgeloos (Editors), Farming the Waters for People and Food. Proceedings of the Global Conference on Aquaculture 2010, Phuket, Thailand. 22-25 September 2010, FAO, Rome and NACA (Network of Aquaculture Centres in Asia - Pacific), Bangkok. pp. 705-717. 